\title{
Cutaneous pilomatrical carcinosarcoma: a case report with molecular analysis and literature review
}

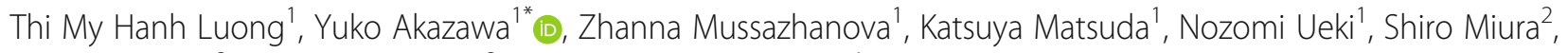
Toshihide Hara ${ }^{3}$, Hiroko Yokoyama ${ }^{3}$ and Masahiro Nakashima ${ }^{1}$

\begin{abstract}
Background: Cutaneous pilomatrical carcinosarcoma (CS) is a very rare biphasic tumor composed of admixed epithelial and mesenchymal malignant cells, with limited information on its pathogenesis. We report a case of pilomatrical CS of the scalp with comparative immunohistochemical and molecular analysis together with a review of the literature.

Case presentation: A 74-year-old woman presented with a rapidly growing long-standing tumor of the scalp. The tumor was surgically resected. Histologically, the tumor was $25 \mathrm{~mm}$ in diameter, and was composed of carcinoma showing a clear pilomatrical differentiation and sarcoma with pleomorphic spindle cells and giant cells. Both epithelial and mesenchymal components shared focal cytoplasmic and/or nuclear accumulation of $\beta$-catenin based on immunohistochemical analysis, although a mutation of exon 3 of the CTNNB1 gene was not detected. Fluorescence in situ hybridization analysis revealed gains of chromosomes 9p21, 3, and 7 in both the epithelial and sarcomatous components.

Conclusions: The current case demonstrated characteristic findings of pilomatricoma and further evidence of partial clonality between the carcinomatous and sarcomatous component, suggesting the possibility of malignant transformation of pilomatricoma. Rapid growth of a pilomatrical tumor should warrant the development of a malignant tumor, including CS.
\end{abstract}

Keywords: Carcinosarcoma, Skin, $\beta$-Catenin

\section{Background}

Carcinosarcoma (CS) is a rare malignant tumor that expresses both mesenchymal and epithelial components. The diagnostic terms of this condition vary, and include sarcomatoid carcinoma, metaplastic carcinoma, and spindle cell carcinoma [1]. Over 100 cases of CS of the skin have been reported [2]; however, only several cases of CS of pilomatrical origin have been reported [2-7]. $\beta$ catenin, a downstream effector in the canonical pathway of Wnt, is suggested to be associated with pilomatrical neoplasms, presenting with nuclear and/or cytoplasmic staining within the tumor upon immunohistochemical

\footnotetext{
* Correspondence: akazaway@nagasaki-u.ac.jp

${ }^{1}$ Department of Tumor and Diagnostic Pathology, Atomic Bomb Disease Institute, Nagasaki University Graduate School of Biomedical Sciences, 1-12-4 Sakamoto, Nagasaki City, Nagasaki 852-8523, Japan

Full list of author information is available at the end of the article
}

analysis [8-12]. Mutation of exon 3 of CTNNB1, which encodes $\beta$-catenin, has also been identified in some pilomatrical neoplasms [8-14]. In addition, LEF1-1, further downstream effector of aberrant $\beta$-catenin in Wnt pathway, has been recently tested as a diagnostic marker for pilomatrical tumors (sensitivity $=100 \%$, specificity $=56 \%$ ) [15]. According to a small number of studies, epithelial and sarcomatous components often share partially identical chromosomal abnormalities, despite their distinct morphologies $[3,16]$. Herein, we present a case of pilomatrical CS of an elderly patient with detailed immunohistochemical and chromosomal abnormality profiling.

\section{Case presentation}

A 74-year-old female patient presented to the hospital with a tumor on the posterior scalp that had grown

(c) The Author(s). 2020 Open Access This article is distributed under the terms of the Creative Commons Attribution 4.0 International License (http://creativecommons.org/licenses/by/4.0/), which permits unrestricted use, distribution, and 
rapidly within two months after a long-standing period over the past 10 years. Ultrasonography revealed a wellcircumscribed solid mass with a diameter of $25 \mathrm{~mm}$ that was partly cystic with calcification. An excision biopsy was performed. Microscopic examination of the lesion revealed a well-demarcated but non-encapsulated dermal mass that had no contact with the superficial epidermis. The tumor showed two closely intermingled components composed of epithelial and mesenchymal malignant tissue (Fig. 1a-f). The epithelial components included basaloid tissue showing follicular differentiation where peripheral atypical basaloid cells transitioned to clear cells and showed degenerative substances at the center of the tumor (Fig. 1a). One area containing eosinophilic "shadow" cells surrounded by foreign body giant cells were observed with some foci of calcification, which was compatible with a remaining benign pilomatricoma (Fig. 1b). A cystic structure was present, which was focally covered with basaloid cells (Fig. 1c). The epithelial component was also admixed with areas of keratinizing atypical squamous cells, indicating squamous cell carcinoma (Fig. 1d). In contrast, the macrophagerich mesenchymal components included pleomorphic spindle tumor cells as well as multinucleated pleomorphic giant cells (Fig. 1e), which was consistent with undifferentiated pleomorphic sarcoma. Part of the sarcomatous lesion also showed features of giant cell tumor showing elongated mononuclear cells and osteoclast-like multinucleated giant cells which resembled a giant cell tumor of the bone (Fig. 1f). The average mitotic indexes were 14 in one high-power field in the carcinomatous area, and 12 in 10 high-power fields in the sarcomatous areas. Atypical mitotic figures were observed frequently in the sarcomatous area. Vascular or perineural invasion was not observed. The restriction margin was negative.

The results of immunohistochemistry are shown in Fig. 2 and Table 1. Both epithelial and mesenchymal components tested positive for P53 (Fig. 2a). The epithelial component tested positive for AE1/AE3 (Fig. 2b), CK5/6, and P40 (data not shown). The nuclear expression of P63 was intense in basaloid cells and showed partial staining in squamous cells (Fig. 2c). The mesenchymal tumor stained diffusely positive for vimentin (data not shown) and partially positive for SMA (Fig. 2d). P63 and AE1/AE3 also stained sparsely positive in the spindle cell element. Macrophages and osteoclast-like giant cells, but not tumor cells stained positively for KP1. A few tumor cells in both epithelial and mesenchymal components stained positively for S100. Based on the above findings, the epithelial component was consistent with pilomatrical carcinoma and the mesenchymal component had features consistent with undifferentiated pleomorphic sarcoma. Consequently, the tumor was diagnosed as one of a pilomatrical CS. The patient has been well without recurrence or metastasis for 45 months.

For further analysis, we investigated $\beta$-catenin and LEF-1 expressions via immunohistochemistry and exons

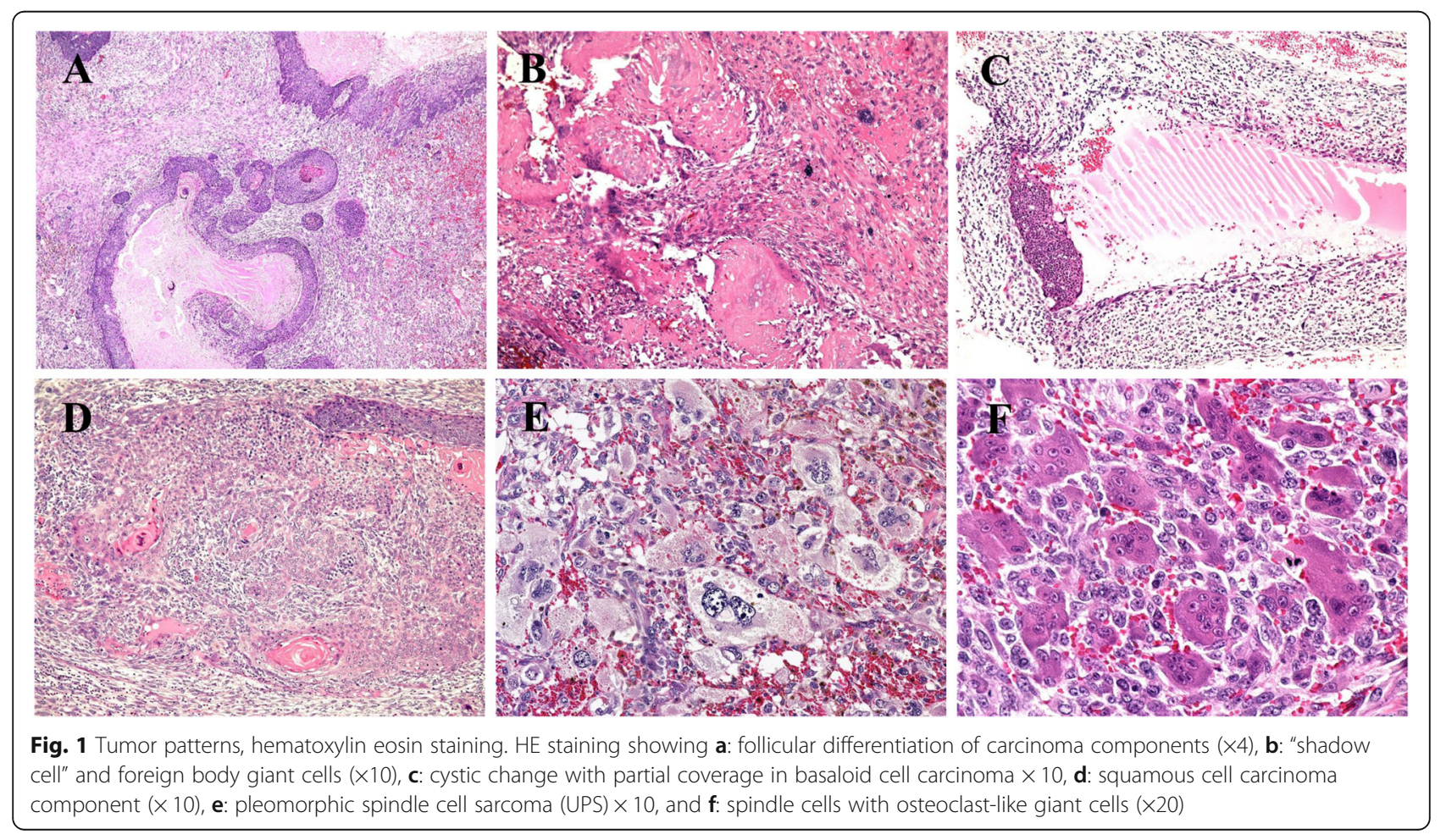




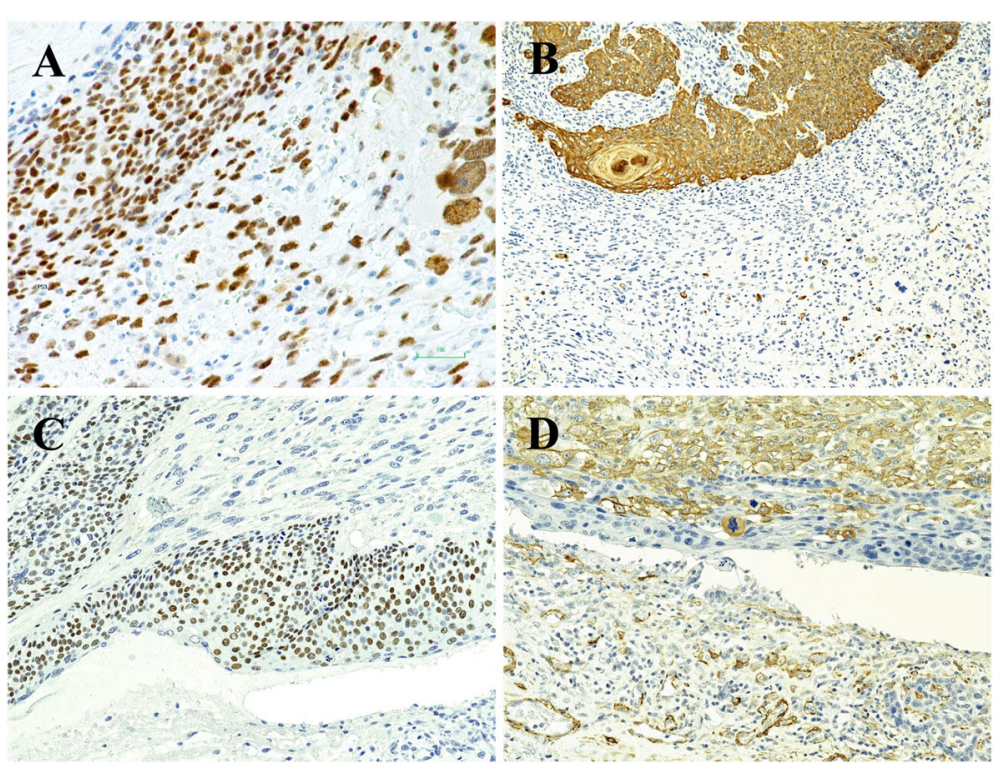

Fig. 2 Immunohistochemistry profile. Immunohistochemistry demonstrated a: positive P53 staining in the nucleus of both carcinoma and sarcoma components $(\times 20)$, b: positive AE1/AE3 in the carcinomatous component and scattered-positive in the sarcomatous component $(\times 4)$, $\mathbf{c}$ : positive P63 nuclear staining in the carcinomatous component $(\times 20)$, and $\mathbf{d}$ : positive SMA staining in the pleomorphic spindle cells and negative staining in the carcinomatous component $(\times 20)$

3, 4, and 5 of the CTNNB1 gene via polymerase chain reaction assay and sequencing. Cytosolic and/or nuclear staining of $\beta$-catenin, termed 'abnormal type $\beta$-catenin expression' in this study, was partially observed in both components, apart from the sarcomatous tumor component which showed a giant cell tumor pattern (Fig. 3a). LEF1 expression was oberved in nuclei of sarcomatous components but very few in carcinomatous components, which may be transitional cells between basaloid to squamoid (Fig. 3b). A CTNNB1 mutation was not detected in exons 3, 4, or 5 of the CTNNB1 gene. Both carcinomatous and sarcomatous components stained diffusely positive for P16 (Fig. 3c). Fluorescence in situ hybridization (FISH) analysis (Fig. 4, Table 2) revealed an increase in the copy number of chromosomes $9 \mathrm{p} 21$ (CDKN2A, p16 gene), 3 , and 7 in both components. A gain in the copy number of chromosome 17 was present in the sarcomatous lesion, whereas the change was minimal in the carcinomatous area, showing a pattern similar to the normal epithelium surrounding the tumor.

Table 1 Results of immunohistochemical analysis of the tumor

\begin{tabular}{|c|c|c|c|}
\hline \multirow[t]{2}{*}{ Markers } & \multicolumn{3}{|l|}{ Tumor component } \\
\hline & Basaloid epithelial component & Squamoid epithelial component & Sarcoma \\
\hline AE1/AE3 & + & + & $+/$ - scattered \\
\hline E-cadherin & - & $+/-$ focal & - \\
\hline CK5/6 & + & + & - \\
\hline P40 & + & + & - \\
\hline P53 & + & + & + \\
\hline P16 & + & + & + \\
\hline P63 & + & $+/-$ focal & +/- scattered \\
\hline CD34 & - & - & - \\
\hline Vimentin & - & - & + \\
\hline SMA & - & - & $+/-$ focal \\
\hline Caldesmon & - & - & - \\
\hline$\beta$-catenin & normal type & abnormal type & abnormal type \\
\hline LEF-1 & - & $+/-$ scattered and focal & + \\
\hline
\end{tabular}




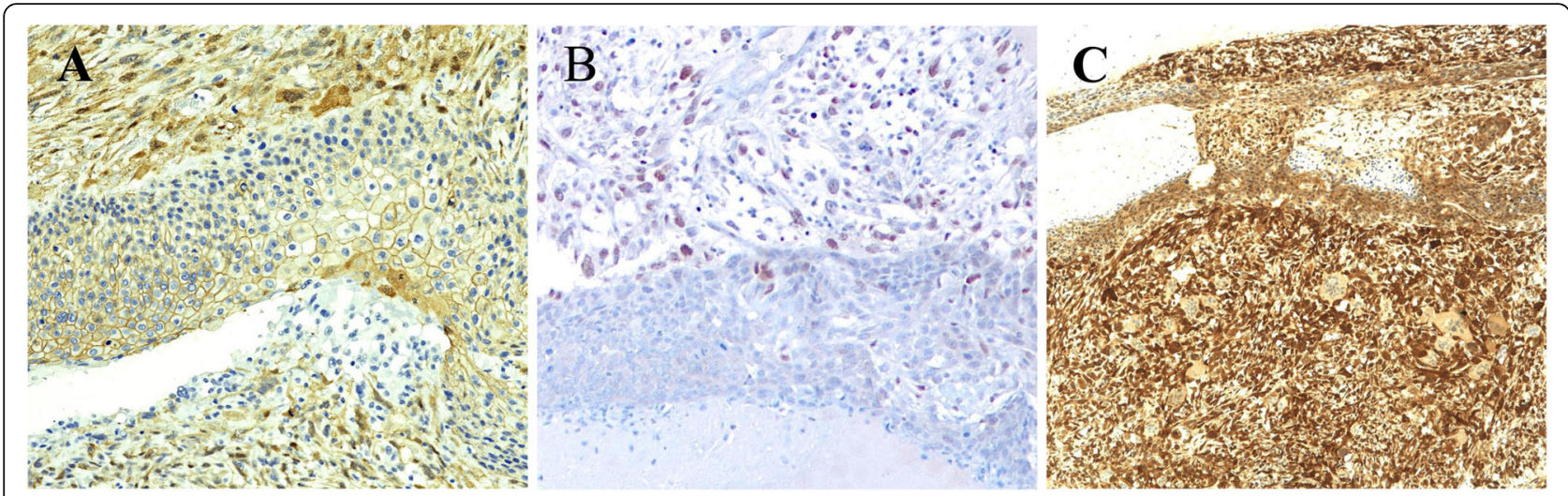

Fig. 3 Assessment of $\beta$-catenin, LEF-1 and P16. a: $\beta$-catenin showed normal type (membranous positive) in the carcinomatous component and abnormal type (cytoplasmic and/or nuclear positive) in the sarcomatous component ( $\times 20)$. b: LEF-1 expression is obviously found in nuclei of sarcomatous components but very few in carcinomatous components $(\times 10)$. c: P16 yielded positive results in the cytoplasm and nuclei of both components $(\times 10)$

\section{Discussion}

Primary pilomatrical CS is a rare condition, with only several cases reported in the English literature to our knowledge [2-7]. Summaries of information regarding the present case and other cases of pilomatrical or cutaneous CS are shown in Tables 3 and 4, respectively. Most cases of cutaneous CS show aggressive clinical features with a rapid growth phase varying from days to months, which follows a long-standing phase lasting up to several decades $[1,2,17,18]$. In our case, the tumor had undergone a 10-year-long slow growth phase followed by rapid growth within 2 months, suggesting that this tumor had clinically transformed from a benign state. Although no exon 3 mutation of CTNNB1 gene was found, an abnormal expression of $\beta$-catenin was focally observed in both the epithelial and sarcomatous
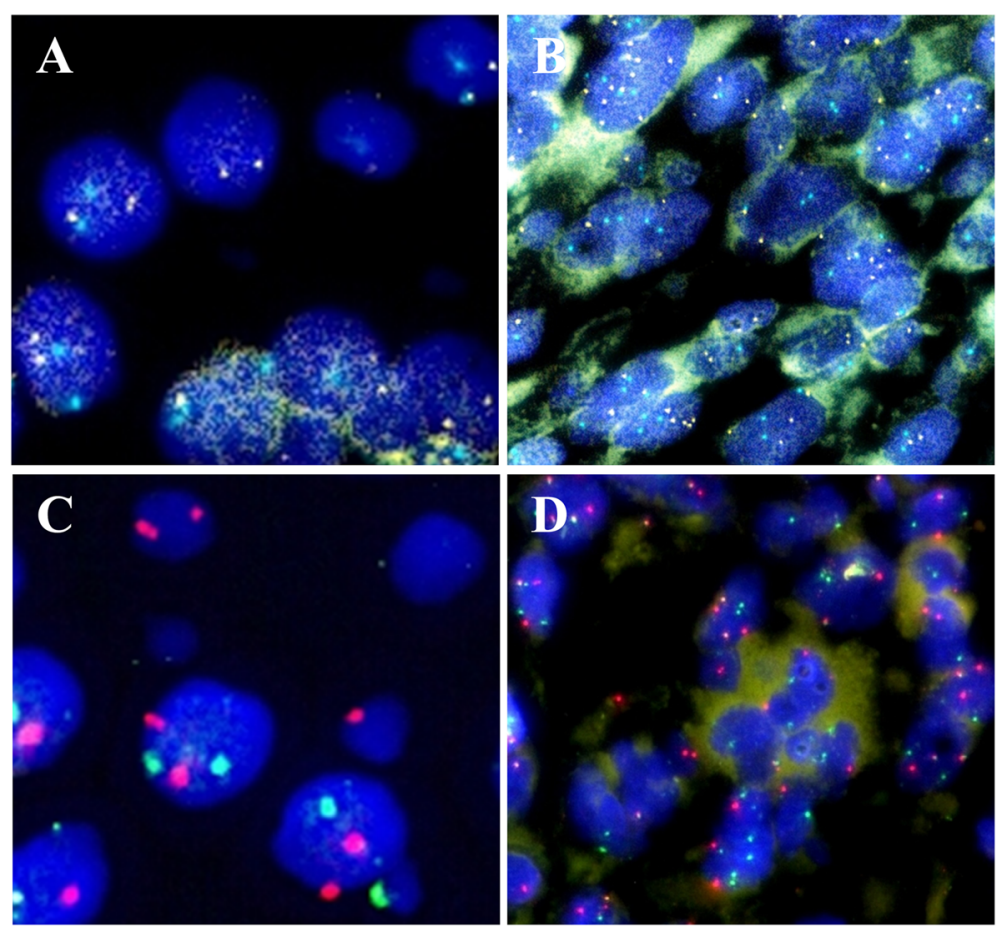

Fig. 4 FISH analysis with probes of chromosome 9p21 (gold), 17 (aqua), 3 (red) and 7 (green). a, c: Benign squamous cell epithelium, where one or two signals per one nucleus is observed for each probe. $\mathbf{b}$, $\mathbf{d}$ : Sarcomatous component of the tumor, where varying copy number gains is observed with an increase in the copy numbers of chromosomes 9p21 (CDKN2A, p16 gene), 3, 7, and 17 
Table 2 Comparison of chromosomal aberrations among benign, carcinomatous, and sarcomatous components

\begin{tabular}{|c|c|c|c|c|c|c|c|c|c|}
\hline \multirow{2}{*}{$\begin{array}{l}\text { Pattern } \\
\text { Chromosomes }\end{array}$} & \multicolumn{3}{|c|}{ Benign epithelium $(n=6)$} & \multicolumn{3}{|c|}{ Carcinoma $(n=13)$} & \multicolumn{3}{|c|}{ Sarcoma $(n=21)$} \\
\hline & Mean \pm SD & Minimum & Maximum & Mean \pm SD & Minimum & Maximum & Mean \pm SD & Minimum & Maximum \\
\hline $9 p 21$ & $0.9 \pm 0.14$ & 0.7 & 1 & $1.6 \pm 0.3$ & 1.1 & 2.1 & $1.8 \pm 0.5$ & 1.1 & 2.9 \\
\hline 3 & $1.1 \pm 02$ & 0.9 & 1.3 & $2.2 \pm 0.3$ & 1.8 & 2.8 & $2.6 \pm 0.6$ & 1.5 & 4.4 \\
\hline 7 & $1.1 \pm 0.2$ & 0.8 & 1.3 & $2.3 \pm 0.4$ & 1.6 & 2.9 & $2.7 \pm 0.5$ & 1.8 & 3.6 \\
\hline 17 & $1.1 \pm 0.1$ & 0.9 & 1.2 & $1.2 \pm 0.2$ & 1.0 & 1.6 & $1.6 \pm 0.4$ & 1.2 & 2.6 \\
\hline
\end{tabular}

All values were calculated using the ratio of the centromere or gene on the nuclei

Abbreviation: SD standard deviation

components of the lesion. Basaloid pattern showed membranous or cytoplasmic positive while squamous and sarcomatous patterns showed cytoplasmic and nuclear expression. A majority of pilomatrical tumors have been reported to show cytoplasmic and/or nuclear $\beta$ catenin expression via immunohistochemistry [8-12]. CTNNB1 gene mutation, which is considered to force $\beta$ catenin expression, has been indicated in the development of follicular tumors; a mutation at exon 3 of the CTNNB1 gene was also found in $61 \%$ [8-10] to $100 \%$ [12]. On the other hand, in our case, LEF-1 expression was obviously found in nuclei of sarcomatous components but very few in carcinomatous components. This staining pattern corresponds to the pattern of aberrant beta-catenin expression, suggesting involvement of activated Wnt pathway during sarcomatous transformation. The LEF-1 immunoreactivity in present case is different from the results of Tumminello et al. (2018) which found that LEF-1 was strong and diffuse positive in basaloid cells of pilomatrical tumor [15]. By immunofluorescence analysis, the study of Chan et al. (1999) also showed that LEF-1 expression was prominently found in nuclei of the proliferating cells of pilomatricomas [9]. Although the $\beta$-catenin and LEF-1 expression in our case are different from previous reports of pilomatrical tumors, aberrant $\beta$-catenin expression in sarcomatous

Table 3 Summary information of 7 cases of pilomatrical carcinosarcoma

\begin{tabular}{|c|c|c|c|c|c|c|c|}
\hline & $\begin{array}{l}\text { Hanly et al., } \\
1994 \text { [7] }\end{array}$ & $\begin{array}{l}\text { Scholl et al., } \\
2010[4]\end{array}$ & $\begin{array}{l}\text { Clark et al., } 2017 \\
\text { [2] }\end{array}$ & $\begin{array}{l}\text { Suyama et al., } \\
2017 \text { [5] }\end{array}$ & Leecy et al., 2018 [3] & $\begin{array}{l}\text { Mori et al., } \\
2019 \text { [6] }\end{array}$ & Present case \\
\hline Age & 36 & 23 & 77 & 73 & 87 & 100 & 74 \\
\hline Sex & Male & Male & Male & Male & Female & Female & Female \\
\hline $\begin{array}{l}\text { Quiescent } \\
\text { period }\end{array}$ & & & $>24$ months & 6 months & 4 years & $\begin{array}{l}\text { Several } \\
\text { decades }\end{array}$ & 10 years \\
\hline Ulcer & + & - & & - & - & - & - \\
\hline Size $(\mathrm{cm})$ & 4 & & 5 & 2 & 1.6 & 1.5 & 2.5 \\
\hline Site & Cheek & Periauricular & Cheek & Cheek & Hand & Temple & Scalp \\
\hline $\begin{array}{l}\text { Epithelial } \\
\text { component }\end{array}$ & $\begin{array}{l}\text { Benign } \\
\text { pilomatrixoma }\end{array}$ & $\begin{array}{l}\text { Benign } \\
\text { pilomatrixoma }\end{array}$ & $\begin{array}{l}\text { Pilomatrical }^{a} \\
\text { component } \\
+ \text { BCC }\end{array}$ & $\begin{array}{l}\text { Malignant } \\
\text { pilomatricoma }\end{array}$ & Malignant pilomatricoma & $\begin{array}{l}\text { Malignant } \\
\text { pilomatricoma }\end{array}$ & $\begin{array}{l}\text { Malignant } \\
\text { pilomatricoma + } \\
\text { SCC }\end{array}$ \\
\hline $\begin{array}{l}\text { Mesenchymal } \\
\text { component }\end{array}$ & $\begin{array}{l}\text { Undifferentiated } \\
\text { pleomorphic } \\
\text { sarcoma }\end{array}$ & $\begin{array}{l}\text { Spindle cell } \\
\text { sarcoma }\end{array}$ & $\begin{array}{l}\text { Undifferentiated } \\
\text { pleomorphic } \\
\text { sarcoma }\end{array}$ & $\begin{array}{l}\text { Spindle cell } \\
\text { sarcoma }\end{array}$ & $\begin{array}{l}\text { Undifferentiated } \\
\text { pleomorphic sarcoma }\end{array}$ & $\begin{array}{l}\text { Spindle cell } \\
\text { sarcoma }\end{array}$ & $\begin{array}{l}\text { Undifferentiated } \\
\text { pleomorphic } \\
\text { sarcoma }\end{array}$ \\
\hline$\beta$-catenin IHC & & & & $\begin{array}{l}\text { Abnormal type } \\
\text { in basaloid } \\
\text { cells in the } \\
\text { epithelial } \\
\text { component }\end{array}$ & $\begin{array}{l}\text { Normal type in basaloid } \\
\text { cells in the epithelial } \\
\text { component }\end{array}$ & $\begin{array}{l}\text { Abnormal } \\
\text { type in both } \\
\text { component }\end{array}$ & $\begin{array}{l}\text { Abnormal type } \\
\text { In both } \\
\text { component }\end{array}$ \\
\hline $\begin{array}{l}\text { CTNNB1 } \\
\text { sequencing }\end{array}$ & & & & $\begin{array}{l}\text { Exon } 3 \text { wild } \\
\text { type }\end{array}$ & & & $\begin{array}{l}\text { Exon 3, 4, } 5 \text { wild } \\
\text { type }\end{array}$ \\
\hline $\begin{array}{l}\text { Chromosomal } \\
\text { abnormality }\end{array}$ & - & - & - & - & $\begin{array}{l}\text { CGH: Homozygous } \\
\text { deletion of chr } 17 q 25 \text {, } \\
9 p 21 ; 9 p 24.1-p 13.2 \text { and } \\
\text { 20p13-p11.1 gain in both } \\
\text { components }\end{array}$ & - & $\begin{array}{l}\text { FISH: varying gains } \\
\text { of copy number of } \\
9 p 21, \text { Chr 3, 7, } 17 \\
\text { in both } \\
\text { component }\end{array}$ \\
\hline
\end{tabular}

Abbreviations: (+) present, (-) absent, BCC basal cell carcinoma, SCC squamous cell carcinoma, Chr chromosome, CGH comparative genomic hybridization, FISH fluorescence in situ hybridization

${ }^{a}$ Not specified whether benign or malignant

Blank spaces indicate that no information was available 
Table 4 Comparison of the present case and other reported cases of cutaneous carcinosarcoma

\begin{tabular}{|c|c|c|c|c|c|}
\hline \multirow{2}{*}{$\begin{array}{l}\text { Authors } \\
\text { Features }\end{array}$} & \multicolumn{2}{|c|}{ Tran et al (2005) } & \multicolumn{2}{|l|}{ Clark et al (2017) } & \multirow{2}{*}{$\begin{array}{l}\text { Present case } \\
\text { Pilomatrical CS }\end{array}$} \\
\hline & $\begin{array}{l}\text { Epidermal } \\
\text { CS }\end{array}$ & Adnexal CS & Adnexal CS & $\begin{array}{l}\text { Epidermal } \\
\text { CS }\end{array}$ & \\
\hline Age (mean \pm SD) & $\begin{array}{l}73 \pm 11(44- \\
91)\end{array}$ & $58 \pm 16(36-87)$ & $63.3 \pm 16.1$ (36-92) & $\begin{array}{l}76 \pm 12(41- \\
98)\end{array}$ & 74 \\
\hline Sex ratio (male: female) & $17: 7$ & $8: 10$ & 0.84 & 2.2 & Female \\
\hline $\begin{array}{l}\text { Site at head and neck, } \\
\text { prevalence }\end{array}$ & $46 \%$ & $44 \%$ & $45.8 \%$ & $58.6 \%$ & Scalp \\
\hline Ulceration prevalence & $48 \%$ & $33 \%$ & & & Not evident \\
\hline Epithelial component & $\begin{array}{l}\text { BCC } 54 \% \\
\text { SCC } 58 \%\end{array}$ & $\begin{array}{l}\text { Spiradenocarcinoma 56\% } \\
\text { Adenocarcinoma } 17 \% \\
\text { Matrical carcinoma } 6 \%\end{array}$ & $\begin{array}{l}\text { Spiradenocarcinoma } \\
50 \% \\
\text { Trichogenic carcinoma } \\
25 \% \\
\text { Pilomatrical carcinoma } \\
1 \%\end{array}$ & $\begin{array}{l}\text { BCC } 63.2 \% \\
\text { SCC4 } 5.9 \%\end{array}$ & $\begin{array}{l}\text { Pilomatrical } \\
\text { carcinoma+SCC }\end{array}$ \\
\hline \multicolumn{6}{|l|}{ Mesenchymal component } \\
\hline UPS (AFX) & $70 \%$ & $56 \%$ & $74.9 \%$ & $67.7 \%$ & UPS \\
\hline Osteosarcoma & $35 \%$ & $38 \%$ & $16.7 \%$ & $26.4 \%$ & \\
\hline
\end{tabular}

Abbreviations: SD standard deviation, CS carcinosarcoma, AFX atypical fibroxanthoma, UPS undifferentiated pleomorphic sarcoma, $B C C$ basal cell carcinoma, SCC squamous cell carcinoma

Blank spaces indicate that no information was available

component was concordant with previous reports of pilomatrical CS $[5,6]$. Furthermore, previous report of pilomatrical CS investigating both $\beta$-catenin expression and CTNNB1 gene exon 3 mutation showed aberrant $\beta$ catenin expression in the tumor without mutation [5], which is consistent with our case. We also note that no mutations were found in exons 4 and 5 . These results suggest the presence of alteration other than CTNNB1 exons 3-5 mutation or other mechanism which activates Wnt pathway during carcinogengesis of pilomatrical CS. Further study is required to clarify the molecular mechanism with accumulation of cases. The results regarding $\beta$-catenin expression in previous and our cases are presented in Table 3.

The association of $\mathrm{p} 16$ overexpression and deletion of the $p 16$ gene $(C D K N 2 a, 9 \mathrm{p} 21)$ with high grade histology and unfavorable prognosis have been recently reported in various cancers [19-24]. In the present case, immunohistochemical analysis demonstrated overexpression of p16 in both components of the tumor (Fig. 3b) and fluorescence in situ hybridization analysis demonstrated an increased copy number of 9p21 (CDKN2A, p16 gene) in both epithelial and sarcomatous components (Fig. 4, Table 2). Furthermore, we observed gains in chromosomes 3 and 7 in both components. Very limited numbers of studies have presented chromosomal aberrations in cutaneous CS, which mainly describes loss of 9p21 or $9 \mathrm{p}$ in both carcinomatous and sarcomatous components $[3,16]$. Although the chromosome gained or lost varies among the cases, they seem to harbor, at least in part, similar chromosomal abnormalities.
There is controversy regarding how CS develops [2527]. The collision tumor theory suggests that two independent tumors collide, while the composition theory suggests that the mesenchymal component results from pseudo-sarcomatous reaction within the epithelial malignancy. The combination theory posits that both malignant components arise from a common pluripotential stem cell that subsequently undergoes divergent differentiation early in the evolution of the tumor. The conversion theory posits that the sarcomatous component results from the transformation of the epithelial component. Our case is suggestive of the conversion theory since the patterns of chromosomal abnormality indicate shared features between the sarcomatous and carcinomatous components of CS, as well as some distinct patterns. In addition, we observed positivity of AE1/AE3 and P63, not only in the epithelial component but also partially in the sarcomatous component. Further, as seen in our case as well as previous reports, CS developed from a seemingly benign lesion after a long-standing period. Taken together, these pieces of evidence suggest the presence of a benign pilomatricoma, which progressed to a carcinoma, and finally transformed into a sarcoma. The presence of a distinct pilomatrical component in our case further supports the conversion theory. However, combination theory cannot be excluded since molecular changes that are common between epithelial and mesenchymal component could have occurred in a primitive tumor cell, which subsequently diverged to different tumor components after additional genetic alterations. 
In summary, we have presented a rare case of pilomatrical CS of the scalp. Our morphological and molecular analysis indicated a malignant transformation of carcinoma from a pilomatricoma, which ultimately developed into a sarcoma. As CS presents with aggressive features including remote metastasis which can be fatal, sudden growth of pilomatrical tumors should be managed promptly with caution.

\section{Abbreviations}

AFX: Atypical fibroxanthoma (dermal type of UPS); CS: Carcinosarcoma; UPS: Undifferentiated pleomorphic sarcoma

\section{Acknowledgements}

We thank Satomi Yokoyama, Tae Kitano, Takahiro Motoyama, and Yuko Araki for their excellent technical and secretary support.

\section{Authors' contributions}

$\mathrm{HL}$ performed the FISH analysis, collected imaging data, and wrote the manuscript. SM and MN made the final diagnosis of this disease. YA collected the clinical data and wrote the manuscript. HY was the surgeon who operated on the patient and TH interpreted the patient data. NU and KM helped to perform the histological and immunohistochemical examination. ZM performed the molecular analysis. All authors have read and approved the final manuscript

\section{Funding}

This work was supported in part by the Atomic Bomb Disease Institute, Nagasaki University, Joint Research by Hiroshima University, Nagasaki University, and Fukushima Medical University Research Base for Radiation Accidents.

\section{Availability of data and materials}

Not applicable.

\section{Ethics approval and consent to participate} Not applicable.

\section{Consent for publication}

The patient provided written informed consent for publication of this case report.

\section{Competing interests}

The authors declare that they have no competing interests.

\section{Author details}

${ }^{1}$ Department of Tumor and Diagnostic Pathology, Atomic Bomb Disease Institute, Nagasaki University Graduate School of Biomedical Sciences, 1-12-4 Sakamoto, Nagasaki City, Nagasaki 852-8523, Japan. ${ }^{2}$ Department of Pathology, National Hospital Organization Nagasaki Medical Center, Omura 856-8562, Nagasaki, Japan. ${ }^{3}$ Department of Dermatology, Isahaya General Hospital, Isahaya, Japan.

Received: 23 November 2019 Accepted: 15 January 2020

Published online: 31 January 2020

\section{References}

1. Tran TA, Muller S, Chaudahri PJ, Carlson JA. Cutaneous carcinosarcoma: adnexal vs. epidermal types define high-and low-risk tumors. Results of a meta-analysis. J Cutan Pathol. 2005;32(1):2-11.

2. Clark JJ, Bowen AR, Bowen GM, Hyngstrom JR, Hadley ML, Duffy K, et al. Cutaneous carcinosarcoma: a series of six cases and a review of the literature. J Cutan Pathol. 2017;44(1):34-44

3. Leecy T, Ardakani NM, Harvey NT, Wood BA. Pilomatrical carcinosarcoma: report of a case with comparative genomic hybridisation analysis. Pathology. 2018;50(5):571-3.

4. Scholl P, Snyder N, Patt D, Talbott B. Pilomatrical carcinosarcoma. Otolaryngol Head Neck Surg. 2010;143(5_suppl):36-7.
5. Suyama T, Momose S, Yokoyama M, Kikuchi J, Izaki S, Arai E, et al. Pilomatrical carcinosarcoma of the cheek: Immunohistochemical and molecular analysis of beta-catenin. Pathol Int. 2017;67(6):324-6.

6. Mori D. Pilomatrical carcinosarcoma of the temple: a case report. J Cutan Pathol. 2019;46(4):267-70.

7. Hanly M, Allsbrook W, Pantazis C, Lane R, Porubsky E, Mann E. Pilomatrical carcinosarcoma of the cheek with subsequent pulmonary metastases. A case report. Am J Dermatopathol. 1994;16(2):196-200.

8. Xia J, Urabe K, Moroi Y, Koga T, Duan H, Li Y, et al. Beta-catenin mutation and its nuclear localization are confirmed to be frequent causes of Wnt signaling pathway activation in pilomatricomas. J Dermatol Sci. 2006;41(1): $67-75$.

9. Chan E, Gat U, McNiff JM, Fuchs E. A common human skin tumour is caused by activating mutations in $\beta$-catenin. Nat Genet. 1999;21(4):410.

10. Hassanein A, Glanz S. $\beta$-Catenin expression in benign and malignant pilomatrix neoplasms. Br J Dermatol. 2004;150(3):511-6.

11. Kim YS, Shin DH, Choi JS, Kim K-H. The immunohistochemical patterns of the $\beta$-catenin expression in pilomatricoma. Ann Dermatol. 2010;22(3):284-9.

12. Lazar AJ, Calonje E, Grayson W, Dei Tos AP, Mihm MC Jr, Redston M, et al. Pilomatrix carcinomas contain mutations in CTNNB1, the gene encoding $\beta$ catenin. J Cutan Pathol. 2005;32(2):148-57.

13. Cornejo KM, Deng A. Pilomatrix carcinoma: a case report and review of the literature. Am J Dermatopathol. 2013;35(3):389-94.

14. Nishioka M, Tanemura A, Yamanaka T, Tani M, Miura H, Asakura M, et al. Pilomatrix carcinoma arising from pilomatricoma after 10-year senescent period: Immunohistochemical analysis. J Dermatol. 2010;37(8):735-9.

15. Tumminello K, Hosler GA. CDX2 and LEF-1 expression in pilomatrical tumors and their utility in the diagnosis of pilomatrical carcinoma. J Cutan Pathol. 2018;45(5):318-24.

16. Harms PW, Fullen DR, Patel RM, Chang D, Shalin SC, Ma L, et al. Cutaneous basal cell carcinosarcomas: evidence of clonality and recurrent chromosomal losses. Hum Pathol. 2015;46(5):690-7.

17. Syme-Grant J, Syme-Grant NJ, Motta L, Stevenson JH, Evans AT. Are primary cutaneous carcinisarcomas underdiagnosed? Five cases and a review of the literature. J Plast Reconstr Aesthet Surg. 2006;59(12):1402-8.

18. Arık D, Kulaçoğlu S. Cutaneous carcinosarcoma: a case report and review of the theories on histogenesis. Correspondance. 2013.

19. Lebok P, Roming M, Kluth M, Koop C, Özden C, Taskin B, et al. p16 overexpression and 9p21 deletion are linked to unfavorable tumor phenotype in breast cancer. Oncotarget. 2016;7(49):81322.

20. Aravidis C, Panani AD, Kosmaidou Z, Thomakos N, Rodolakis A, Antsaklis A Detection of numerical abnormalities of chromosome 9 and p16/CDKN2A gene alterations in ovarian cancer with fish analysis. Anticancer Res. 2012; 32(12):5309-13.

21. Elenitoba-Johnson KS, Gascoyne RD, Lim MS, Chhanabai M, Jaffe ES, Raffeld M. Homozygous deletions at chromosome 9p21 involving p16 and p15 are associated with histologic progression in follicle center lymphoma. Blood. 1998:91(12):4677-85.

22. Brownhill S, Taylor C, Burchill S. Chromosome 9p21 gene copy number and prognostic significance of p16 in ESFT. Br J Cancer. 2007:96(12):1914.

23. Michaud K, de Tayrac M, D'Astous M, Paquet C, Gould PV, Saikali S. Impact of $9 p$ deletion and p16, Cyclin D1, and Myc hyperexpression on the outcome of anaplastic oligodendrogliomas. PLoS One. 2018;13(2):e0193213.

24. Langendijk J, Psyrri A. The prognostic significance of p16 overexpression in oropharyngeal squamous cell carcinoma: implications for treatment strategies and future clinical studies: Oxford University Press; 2010

25. Wick M, Swanson P, editors. Carcinosarcomas: current perspectives and an historical review of nosological concepts. Seminars in diagnostic pathology; 1993.

26. McCluggage W. Malignant biphasic uterine tumours: carcinosarcomas or metaplastic carcinomas? J Clin Pathol. 2002:55(5):321-5.

27. Loh TL, Tomlinson J, Chin R, Eslick GD. Cutaneous carcinosarcoma with metastasis to the parotid gland. Case Rep Otolaryngol. 2014;2014:173235.

\section{Publisher's Note}

Springer Nature remains neutral with regard to jurisdictional claims in published maps and institutional affiliations. 